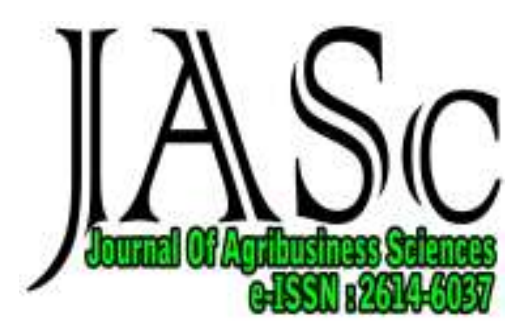

Oktober 2017 Volume 01 No. 01

\title{
THE POTENTIAL AND CONTRIBUTIONS HANDICRAFT OF PALM IN HOUSEHOLD INCOME
}

\section{POTENSI DAN KONTRIBUSI USAHA KERAJIANAN TEPAS SAWIT TERHADAP PENDAPATAN RUMAH TANGGA}

\author{
Sasmita Siregar, Khairunnisa Rangkuti dan Dedi Siswanto \\ Jurusan Agribisnis Fakultas Pertanian \\ Universitas Muhammadiyah Sumatera Utara \\ Email : sasmitasiregar@yahoo.co.id
}

\begin{abstract}
This study aims to determine: First, the magnitude Contributions side: oil on household income in the study area. Second, potential side: palm handicraft business in the area of research. Third, constraints - constraints in the development of craft business side: the palm area of research. Fourth, the business development strategy craft palm side: in the study area. Sampling method using census method that takes all the existing sample research area. The analytical method used is descriptive analysis and SWOT analysis.The research result is that the contribution of the craft business side: oil on household income in the village Rabuhit is Rp 44.22825 million ie 56\% of total household income. Business development strategies craft side: the oil can be seen from the potential and constraints - constraints faced by producers are expanding the marketing network, the expansion of handicraft business side: oil, providing added value / a touch of creativity that makes the motive side: oil more attractive, maintain good relations with the consumer side: oil and using existing knowledge about the area plantation palm frond waste generators to maintain the availability of the raw materials for the production of handicraft of palm.
\end{abstract}

Keywords : Potential, Contributions, Profits

\section{ABSTRAK}

Penelitian ini bertujuan untuk mengetahui :Pertama, besarnya Kontribusi tepas sawit terhadap pendapatan rumah tangga di daerah penelitian. Kedua,potensi usaha kerajinan tepas sawit di daerah penelitian.Ketiga,kendala-kendala dalam pengembangan usaha kerajinan tepas sawit didaerah penelitian. Keempat, strategi pengembangan usaha kerajinan tepas sawit di daerah penelitian.Metode penarikan sampel menggunakan metode sensus yaitu mengambil semua sampel yang ada didaerah penelitian. Metode analisis yang digunakan adalah analisis secara deskriptif dan analisis SWOT.Hasil penelitian adalah bahwa kontribusi usaha kerajinan tepas sawit terhadap pendapatan rumah tangga di Desa Rabuhit adalah sebesarRp 44.228.250 yaitu 56\% dari total pendapatan rumah tangga.Strategi pengembangan usaha kerajinan tepas sawit dapat dilihat dari potensi dan kendala-kendalayang dihadapi pengrajin adalah memperluas jaringan pemasaran, perluasan usaha kerajinan tepas sawit, memberikan nilai tambah/sentuhan kreatifitas yaitu membuat motif tepas sawit yang lebih menarik, menjaga hubungan baik dengan konsumen tepas sawit dan menggunakan pengetahuan yang ada tentang wilayah perkebunan penghasil limbah pelepah sawit untuk menjaga ketersediaan bahan baku produksi tepas sawit.

Kata Kunci : Kontribusi, Potensi, Pendapatan

\section{A.PENDAHULUAN}

Negara Indonesia merupakan negara pertanian, artinya pertanian memegang peranan penting dari keseluruhan perekonomian nasional.Hal ini dapat ditunjukkan dari banyaknya penduduk yang bekerja pada sektor pertanian atau dari produk nasional yang berasal dari pertanian. Pertanian merupakan sektor primer dalam perekonomian, namun hal tersebut tidak lepas dari peranan subsektor pertanian lainnya yang menjadi pendukung untuk mempercepatlaju pertumbuhan perekonomian nasional $^{1}$
Pembangunan pertanian harus dipandang dari dua pilar utama secara terintegrasi dan tidak bisa dipisahkan yaitu pertama, pilar pertanian primer (on-farm agriculture/agribusiness) yang merupakan kegiatan usahatani yang menggunakan sarana dan prasarana produksi (input factors) untuk menghasilkan produk pertanian primer.Kedua, pilar pertanian sekunder (down- stream agriculture/agribusiness) sebagai kegiatan meningkatkan nilai tambah produk pertanian primer melalui pengolahan (agroindustri) beserta distribusi dan perdagangannya ${ }^{2}$ 
Industrialisasi pertanian dikenal dengan nama agroindustri, dimana agroindustri dapat menjadi salah satu pilihan strategis dalam menghadapi masalah dalam upaya peningkatan perekonomian masyarakat di pedesaan serta mampu menciptakan kesempatan kerja bagi masyarakat yang hidup di pedesaan. Sektor industri pertanian merupakan suatu sistem pengolahan secara terpadu antara sektor pertanian dengan sektor industri guna mendapatkan nilai tambah dari hasil pertanian. Agroindustri merupakan usaha untuk meningkatkan efisiensi sektor pertanian hingga menjadi kegiatan yang sangat produktif melalui proses modernisasi pertanian. Modernisasi di sektor industri dalam skala nasional dapat meningkatkan penerimaan nilai tambah sehingga pendapatan ekspor akan lebih besar ${ }^{3}$

Perkebunan merupakan bagian dari sektor pertanian,melalui tanaman kelapa sawit sebagai salah satu primadonanya telahmenjadi sumber penghasil devisa non migas bagi Indonesia, penyerap tenaga kerja perkebunan,sumber pendapatan bagi petani.Cerahnya prospek tanaman kelapa sawit ini telah mendorong pemerintah Indonesia untuk memacu pengembangan areal perkebunan kelapa sawit. Kelapa sawit merupakan komoditi yang paling mendominasi luas areal perkebunan Indonesia. Pertumbuhan luas areal perkebunan rakyat mencapai 8,13 persen pertahun, diikuti perkebunan swasta 1,6 persen pertahun dan pertumbuhan perkebunan negara yang relatifkecil, yaitu meningkat rata-rata 1,03 persen pertahun.Selama tahun 2008-2013, luas areal perkebunan kelapa sawit di Indonesia terus berkembang. Proses pemanenan pada perkebunan kelapa sawit selalu diiringi dengan aktivitas pemeliharaan yaitu pemotongan pelepah daun sawit. Dari hasil pengamatan bahwa sebelum proses pemanenan dilakukan pemotongan pelepah daun kelapa sawit, baik pelepah sanggah atau pemotongan pemeliharaan. Diperkebunan yang luas limbah pelepah kelapa sawit ini cukup besar karena selalu ada setiap pemanenan buah sehingga dapat menjadi potensi pemanfaatan yang prospektif.Pelepah kelapa sawit merupakan salah satu limbah perkebunan kelapa sawit yang belum banyak di manfaatkan. Pada tanaman dewasa di temukan 40-50 pelepah atau lebih dengan panjang bisa mencapai 7,5-9 $\mathrm{m}$, dengan produksi perbatang 27 pelepah pertahun, tergantung umur tanaman dan jenis tanah. Pelepah kelapa sawit merupakan hasil sampingan dari pemanenan buah kelapa sawit.Siklus pemangkasan setiap 14 hari, tiap pemangkasan sekitar 3 pelepah daun dengan berat 1 pelepah mencapai $10 \mathrm{~kg}$. Satu ha lahan ditanami sekitar 148 pohon setiap 14 hari dihasilkan $4.440 \mathrm{~kg}$ atau $8.880 \mathrm{~kg} / \mathrm{bulan} / \mathrm{ha}^{4}$

Salah satu bentuk pemanfaatan pelepah sawit lainnya adalah dalam bentuk anyaman yang digeluti masyarakat terutama di daerah pedesaan yaitu pembuatan kerajinan tepas.Tepas merupakan kerajinan tangan yang turuntemurun dari nenek moyang, sebagai masyarakat yang memiliki kerajinan tangan.Tepas adalah hasil karya dari sebagian masyarakat pribumi yang tinggal di desa yang masih kental dengan kerajinan tangan tradisional.Dan kerajinan tangan ini merupakan kerajinan warisan nenek moyang jaman dahulu, terutama pembuatan tepas dengan bahan bambu. Namun seiring dengan perkembangan zaman dan pengetahuan masyarakat saat ini para pengrajin menggunakan pelepah kelapa sawit sebagai bahan baku dalam pembuatan tepas karena lebih mudah untuk mendapatkannya. Pelepah kelapa sawit tersebut dapat diperoleh para pengrajin dari perkebunan rakyat ${ }^{5}$.

Batang dan pelepah kelapa sawit yang sudah tua dan tidak produktif lagi, dapat dimanfaatkan menjadi produk yang bernilai tinggi. Batang kelapa sawit tersebut dapat dibuat fiber board sebagai bahan baku perabot rumah tangga seperti mebel, furniture, atau sebagai papan pertikel. Batang dan pelepah kelapa sawit dapat dipergunakan sebagai bahan baku papan partikel. Karena banyak mengandung komponen kimia kayu seperti lignin (16,19\%), Selulosa $(44,14 \%)$ dan hemiselulosa $(19,28 \%)$. Dari setiap batang kelapa sawit dapat diperoleh kayu sebanyak $0,34 \mathrm{~m}^{3}$. Sifat-sifat yang dimiliki kayu kelapa sawit tidak berbeda jauh dengan kayu-kayu yang biasa digunakan untuk perabot rumah tangga sehingga berpeluang untuk dimanfaatkan secara luas ${ }^{6}$

Pengrajin tepas sawit adalah seseorang yang membuat kerajinan dari bahan pelepah sawit untuk dianyam menjadi tepas. Usaha kerajinan tepas merupakan salah satu jenis usaha dengan memanfaatkan bahan baku pelepah kelapa sawit.Para pengrajin kemudian menganyam bahan baku tersebut menjadi tepas. Tepas biasanya digunakan masyarakat sebagai dinding rumah karena harganya yang relatif terjangkau dan mudah mendapatkannya. Usaha kerajinan tepas didaerah penelitian tergolong masih bersifat sederhana, para pengrajin menggunakan bahan baku dari pelepah sawit yang diperoleh dari perkebunan kelapa sawit milik pemerintah. Tepas merupakan salah satu hasil kerajinan tradisional tangan yang hingga kini masih diminati masyarakat. Karena tepas yang bahan bakunya berasal dari pelepah sawit yang mudah didapat disekeliling rumah sehingga dimanfaatkan oleh masyarakat sebagai 
dinding rumah maupun dimanfaatkan sebagai tambahan pendapatan ${ }^{7}$

Kontribusi adalah Sumbangan pendapatan kerajinan tepas terhadap pendapatan rumah tangga Pendapatan rumahtangga di tidak hanya berasal dari usaha pertanian, tetapi juga dari usaha-usaha di luar sektor pertanian seperti pegawai, pedagang, buruh. Pada sebagian keluarga, usaha pertanian masih merupakan usaha utama dan menjadi sumber pendapatan utama, tetapi bagi sebagian keluarga lainnya, usaha non pertanian merupakan usaha yang utama.Rumahtangga di pedesaan memiliki berbagai macam mata pencarian dalam rangka memenuhi kebutuhannya sekaligus untuk meningkatkan pendapatannya. Pada umumnya pendapatan keluarga di pedesaan berasal lebih dari satu sumber pendapatan. Anggota keluarga bekerja pada berbagai kegiatan dalam rangka menambah pendapatan keluarganya ${ }^{8}$

Di Desa Rabuhit rata-rata penduduknya bermata pencarian sebagai petani, pedagang, serta peternak. Untuk menambah pendapatan rumah tangga keluarga dan memenuhi kebutuhan hidupnya banyak juga masyarakat di Desa Rabuhit bekerja sebagai pengrajin salah satunya sebagai pengrajin tepas, meski usaha kerajinan tepas bukan merupakan usaha pokok, tetapi usaha kerajinan tepas sebagai alternatif usaha yang cukup membantu dalam perekonomian rumah tangga.

Berdasarkan pemaparan diatas maka penulis melakukan penelitian ini untuk mengetahui seberapa besar kontribusi usaha kerajinan tepas sawit terhadap pendapatan rumah tangga, untuk mengetahui potensi pengembangan usaha kerajinan tepas sawit, untuk mengetahui kendala-kendala yang ada dalam pengembangan usaha kerajinan tepas sawit dan untuk mengetahui strategi yang dapat dilakukan dalam pengembangan usaha kerajinan tepas sawit. Karena kerajinan tepas memiliki peluang untuk dikembangkan dan dapat bersaing dengan kerajinan lainnya di Desa Rabuhit.

\section{B. METODE PENELITIAN \\ Metode Penelitian}

Metode penelitian yang digunakan adalah metode studi kasus (case study) yaitu penelitian yang dilakukan dengan melihat langsung kelapangan.Penelitian ini dilaksanakan di Desa Rabuhit, Kecamatan Gunung Maligas, Kabupaten Simalungun.

\section{Metode Penentuan Lokasi}

Pemilihan lokasi ini dilakukan secara sengaja (purposive) dengan pertimbangan bahwa di Desa Rabuhit merupakan daerah penghasil kerajinan tepas pelepah sawit.

\section{Metode Penarikan Sampel}

Metode yang digunakan dalam pengambilan sampel adalah metode sensus (Sampling Jenuh).Sampel yang diambil yaitu sebanyak 25 pengrajin Tepas. ${ }^{9}$

\section{Metode Analisis Data}

Untuk menganalisis besarnya pemanfaatan pelepah kelapa sawit yang dijadikan tepas terhadap pendapatan rumah tangga digunakan rumus :

$$
\begin{array}{ll}
\mathrm{K}=\frac{P 1}{P t R t} & \mathrm{X} 100 \% \ldots . . .{ }^{10} \\
\mathrm{~K} & =\text { Kontribusi pendapatan usaha } \\
& \text { kerajinan tepas sawit terhadap } \\
& \text { pendapatan rumah tangga }(\%) \\
& =\text { Pendapatan usaha kerajinan tepas } \\
& \text { sawit (rp/bulan) } \\
\mathrm{P}_{1} \quad \begin{array}{l}
\text { Pendapatan total rumah tangga } \\
\text { (rp/bulan) }
\end{array} &
\end{array}
$$

Untuk menganalisis potensi pengembangan dan kendala yang dihadapi oleh pengrajin usaha tepas kelapa sawit digunakan analisis deskriptif

Untuk menganalisis strategi pengembangan usaha kerajinan tepas sawit digunakan analisis SWOT. ${ }^{11}$

\section{C.HASIL DAN PEMBAHASAN \\ Kontribusi Pendapatan Usaha Kerajinan Tepas Sawit}

Usaha kerajinan pelepah kelapa sawit yang dijadikan tepas merupakan usaha rumah tangga yang memberikan kontribusi pendapatan terbesar. Hal ini dikarenakan rumah tangga di Desa Rabuhit memang lebih banyak membuat kerajinan pelepah kelapa sawit yang dijadikan tepas dibanding mengusahakan kerajinan lain.Besarnya pendapatan usaha kerajinan tepas sawit di Desa Rabuhit yaitu sebesar Rp 44.228.250 atau 56\% dari total pendapatan rumah tangga pengrajin tepas sawit

\section{Potensi Usaha Kerajinan Tepas Sawit Potensi usaha adalah sebuah kesempatan yang dimiliki dalam mengembangkan usaha dengan melihat kelebihan-kelebihan yang ada untuk dapat dimanfaatkan dalam pengembangan usaha yang dimiliki.Usaha kerajinan tepas merupakan usaha yang bergerak dalam bidang kerajinan tangan yang berbentuk anyaman.Potensi-potensi usaha kerajinan tepas sawitdiantaranya:}

\section{a. Kemudahan Memperoleh Bahan Baku}

Bahan baku untuk membuat tepas sawit yaitu pelepah kelapa sawit. Bahan baku 
merupakan potensi yang dimiliki dalam menjalankan usaha kerajinan tepas sawit mengingat Desa Rabuhit merupakan daerah yang sebagian besar wilayahnya terdiri dari perkebunan kelapa sawit.Dengan penggunaan lahan terbesar di Desa Rabuhit yaitu perkebunan kelapa sawit sebesar 997 ha. Hal ini dapat mendukung persediaan bahan baku berupa pelepah kelapa sawit.

\section{b. Efisiensi Biaya Tenaga Kerja}

Kerajinan tepas sawit di Desa Rabuhit merupakan kerajinan rumah tangga yang menggunakan tenaga kerja keluarga. Dengan penggunaan tenaga kerja dalam keluarga antara $1-2$ tenaga kerja. Sehingga pengrajin tepas sawit dapat melakukan efisiensi biaya tenaga kerja.

\section{c. Modal tidak terlalu besar.}

Modal awal untuk memulai usaha kerajinan tepas sawit tidak terlalu besar hal itu disebabkan karena biaya - biaya produksi yang harus dikeluarkan juga tidak terlalu besar. Biaya yang dikeluarkan pengrajin tepas sawit di Desa Rabuhit dalam membuat tepas sawit hanya biaya tenaga kerja keluarga, biaya transportasi dan biaya dalam membeli peralatan. Peralatan yang digunakan dalam membuat tepas sawit masih menggunakan peralatan yang sederhana seperti kapak, parang, pisau, gergaji, dan broti yang masih mudah ditemukan ditengah - tengah masyarakat dan harganya yang relatif terjangkau.

\section{d. Permintaan pasar cukup tinggi}

Permintaan pasar akan produksi tepas sawit tidak hanya di Desa Rabuhit saja tetapi berasal dari luar Desa Rabuhit diantaranya seperti Desa Sibatu - Batu, Simpang Dua, Perluasan, Raya, Beringin, Karang Sari, Tanjung Pinggir, Panitonga, Simpang Dua, Simpang Empat serta kota Pematang Siantar, Marjanji dan Sidamanik.

Tabel. Produksi Tepas Sawit Per Bulan dari Tahun 2010 Sampai Tahun 2014

\begin{tabular}{cccc}
\hline No & Tahun & Produksi & Permintaan Pasar \\
\hline 1 & 2010 & 2800 lembar/bulan & 3200 lembar/bulan \\
2 & 2011 & 3000 lembar/bulan & 3400 lembar/bulan \\
3 & 2012 & 2900 lembar/bulan & 3000 lembar/bulan \\
4 & 2013 & 3100 lembar/bulan & 3500 lembar/bulan \\
5 & 2014 & 5500 lembar/bulan & 4900 lembar/bulan \\
\hline
\end{tabular}

Sumber : Agen Pembeli Tepas Tahun 2015

Diketahui pada Tabel diatas bahwa permintaan tepas sawit lebih tinggi dari pada produksinya. Sehingga usaha kerajinan tepas sawit di Desa Rabuhit mempunyai potensi untuk dikembangkan. Dan untuk melihat potensi yang dapat dikembangkan dari kerajinan tepas sawit di Desa Rabuhit maka dapat dilakukan perkiraan permintaan pasar akan tepas sawit di masa yang akan datang.
Dalam hal ini perkiraan atau peramalan permintaan pasar terhadap tepas sawit yang akan dilihat yaitu pada 5 tahun yang akan datang dari tahun 2015 - 2019. Menurut Untung Sus Andriyanto dan Abdul Basith (1999)peramalan dapat dilakukan dengan menggunakan metode regresi linier sederhana dengan rumus yaitu $Y=a+b x$

Tabel. Nilai - nilai Yang Diperlukan Untuk Menghitung Koefisien Regresi Linier

\begin{tabular}{|c|c|c|c|c|c|}
\hline Tahun & $\begin{array}{c}\text { Periode } \\
\left(\mathrm{X}_{\mathrm{i}}\right)\end{array}$ & Bobot $X_{i}$ & Permintaan pasar $\left(\mathrm{Y}_{\mathrm{i}}\right)$ & $X_{i}, Y_{i}$ & $\mathrm{X}_{\mathrm{i}}^{2}$ \\
\hline 2010 & 1 & -2 & 3200 lembar/bulan & -6400 & 4 \\
\hline 2011 & 2 & -1 & 3400 lembar/bulan & -3400 & 1 \\
\hline 2012 & 3 & 0 & 3000 lembar/bulan & 0 & 0 \\
\hline 2013 & 4 & 1 & 3500 lembar/bulan & 3500 & 1 \\
\hline 2014 & 5 & 2 & 4900 lembar/bulan & 9600 & 4 \\
\hline Jumlah & 15 & 0 & 18000lembar/bulan & 3300 & 10 \\
\hline $\begin{array}{l}\text { Dari Tabel } \\
\text { berikut: } \\
\sum \mathrm{X}_{\mathrm{i}}=0 \\
\sum \mathrm{Y}_{\mathrm{i}}=179 \\
\sum \mathrm{X}_{\mathrm{i}} \mathrm{Y}_{\mathrm{i}}=33\end{array}$ & tas, dip & nilai - & $\begin{array}{l}\sum \mathrm{X}_{\mathrm{i}}^{2}= \\
\mathrm{n} \\
\text { dari ni } \\
\text { ditentl } \\
a=\underline{\left(\sum \mathrm{Y}\right.}\end{array}$ & $\begin{array}{l}\text { ut mak } \\
\frac{\left.\mathrm{X}_{\mathrm{i}}\right)\left(\sum \mathrm{x}_{\mathrm{i}}\right.}{\left.\mathrm{X}_{1}\right)^{2}}\end{array}$ & a dan b dapat \\
\hline
\end{tabular}


$a=\frac{(17900)(10)-(0)(3300)}{5(10)-(0)^{2}}$

$a=3580$

dan

$b=\frac{n\left(\sum \mathrm{X}_{\mathrm{i}} \cdot \mathrm{Y}_{\mathrm{i}}\right)-\left(\sum \mathrm{X}_{\mathrm{i}}\right)\left(\sum \mathrm{Y}_{\mathrm{i}}\right)}{n\left(\sum \mathrm{X}_{\mathrm{i}}^{2}\right)-\left(\sum \mathrm{X}_{1}\right)^{2}}$

$b=\frac{5(3300)-(0)(17900)}{5(10)-(0)^{2}}$

$b=330$

dengan demikian didapat persamaan regresi

linier $\mathrm{Y}$ atas $\mathrm{X}$, yaitu:

$\mathrm{Y}=3580+330 \mathrm{X}$

Persamaan regresi yang didapat selanjutnya digunakan untuk perkiraan permintaan pasar terhadaptepas sawit tahun 2015 - 2019, dengan perhitungan sebagai berikut:

Permintaan pasar terhadap tepas sawit tahun 2015:

$\mathrm{Y}=3580+330 \mathrm{X}$

$Y=3580+330(6)$

$\mathrm{Y}=5560$
Permintaan pasar terhadap tepas sawit tahun 2016:

$\mathrm{Y}=3580+330(7)$

$Y=5890$

Permintaan pasar terhadap tepas sawit tahun 2017:

$\mathrm{Y}=3580+330(8)$

$\mathrm{Y}=6220$

Permintaan pasar terhadap tepas sawit tahun 2018:

$\mathrm{Y}=3580+330(9)$

$\mathrm{Y}=6550$

Permintaan pasar terhadap tepas sawit tahun 2019:

$\mathrm{Y}=3580+330(10)$

$\mathrm{Y}=6880$

Berikut ini adalah Tabel hasil perkiraan permintaan pasar terhadap tepas sawit di Desa Rabuhit tahun 2015 - 2019.

Tabel. Jumlah Permintaan Pasar Terhadap Tepas Sawit Per Bulan Tahun 2010 - 2014 dan Hasil Perkiraannya Untuk Tahun 2015-2019.

\begin{tabular}{cl}
\hline Tahun & Permintaan Pasar \\
2010 & 3200 lembar/bulan \\
2011 & 3400 lembar/bulan \\
2012 & 3000 lembar/bulan \\
2013 & 3500 lembar/bulan \\
2014 & 4900 lembar/bulan \\
$2015 *$ & 5560 lembar/bulan \\
$2016 *$ & 5890 lembar/bulan \\
$2017 *$ & 6220 lembar/bulan \\
$2018 *$ & 6550 lembar/bulan \\
$2019 *$ & 6880 lembar/bulan \\
\hline & lembarnya. Harga tepas sawit tersebut \\
Dari Tabel diatas dapat dilihat hasil & dikalangan masyarakat merupakan harga yang \\
perkiraan permintaan pasar terhadap tepas sawit & hasil kerajingan anyaman tangan. \\
dengan menggunakan metode regresi linier &
\end{tabular}
sederhana.Diketahui bahwa perkiraan permintaan pasar terhadap tepas sawit per bulannya pada tahun 2015 - 2019 terus mengalami peningkatan.Sehingga dapat ditarik kesimpulan bahwa usaha kerajinan tepas sawit berpotensi untuk dikembangkan.

\section{e. Harga Relatif Terjangkau}

Harga tepas sawit yang diproduksi pengrajin di Desa Rabuhit cukup terjangkau. Harga tepas sawit antara pengrajin tepas yang satu dengan pengrajin tepas lainnya di Desa Rabuhit tidak berbeda, dimana harga ditetapkan oleh pasar.

Harga pasar untuk penjualan tepas sawit adalah Rp. 9.000 dibandingkan dengan tepas dari bambu yaitu Rp. 25.000 per

\section{f. Alternatif Bahan Bangunan}

Tepas sawit berguna sebagai alternatif bangunan seperti:

- Barak yaitu bangunan sementara atau tempat tinggal sementara misalnya untuk pekerja anemer/karyawan tidak tetap suatu perkebunan milik pemerintah maupun swasta.

- Dinding tempel dapur biasanya untuk masyarakat yang tinggal di pinggiran kota. Misalnya untuk dapur rumah karyawan perkebunan.

- Keperluan membuat kandang, pagar serta bangunan usaha bagi masyarakat terutama untuk kalangan pengusaha. 
- Platfon (asbes) sementara bagi orang orang yang sedang bekerja mendirikan bangunan.

\section{Kendala dalam Menjalankan Usaha Kerajinan Tepas Sawit}

\section{a. Modal Pengembangan usaha}

Usaha kerajinan tepas sawit merupakan usaha yang menggunakan modal usaha dalam skala kecil. Untuk pengembangan usaha ke skala yang lebih besar para pengrajin tepas sawit di Desa Rabuhit memerlukan modal yang lebih besar sehingga dapat menambah jumlah produksi tepas sawitnya. Selama ini para pengrajin mengalami kesulitan untuk mendapatkan modal hal itu disebabkan sulitnya mendapatkan bantuan pinjaman modal dari perbankan maupun koperasi yang ada dilingkungan Desa Rabuhit dan tidak adanya bantuan dan perhatian dari pemerintah daerah Desa Rabuhit.

\section{b. Manajemen Usaha}

Usaha kerajinan tepas sawit di Desa Rabuhit menggunakan tenaga kerja dalam keluarga sehingga belum menerapkan manajemen usaha dengan baik. Kurangnya pengetahuan dan kemampuan para pengrajin tentang memanajemen sebuah usaha menjadi kendala dalam pengembangan usaha kerajinan tepas sawit di Desa Rabuhit.

\section{c. Tidak ada dukungan Kelembagaan}

Kurangnya dukungan dan perhatian pemerintah daerah Desa Rabuhit terhadap kerajinan rumah tangga mengakibatkan sulitnya pengrajin tepas sawit dalam mendapat modal.Pengrajin tepas hanya mengandalkan modal sendiri sehingga pendapatan pengrajin tepas sawit di Desa Rabuhit tidak dapat meningkat.

Gambar. Penentuan Strategi dengan Matrik SWOT

\begin{tabular}{|c|c|c|}
\hline IFAS & Kekuatan (S) & Kelemahan (W) \\
\hline & $\begin{array}{l}\text { 1. Bahan baku mudah di } \\
\text { peroleh } \\
\text { 2. Keterampilan pengrajin }\end{array}$ & $\begin{array}{l}\text { 1. Modal terbatas } \\
\text { 2. Kurangnya kreatifitas } \\
\text { motif tepas sawit }\end{array}$ \\
\hline \multicolumn{3}{|l|}{ EFAS } \\
\hline Peluang (O) & Strategi 'SO' & Strategi 'WO' \\
\hline
\end{tabular}

\section{d. Kurangnya Kreatifitas Pengrajin \\ Setiap kerajinan tangan tentunya} membutuhkan kreatifitas dari para pengrajin karena dapat memberi nilai tambah dari hasil produksi kerajinan tersebut. Tepas memiliki beberapa motif atau tampilan diantaranya motif wajik-wajikan (bunga), motif L dan motif biasa. Kurangnya kreatifitas dalam membuat motif tepas sawit yang dilakukan pengrajin tepas sawit di Desa Rabuhit mengakibatkan tidak meningkatnya permintaan akan tepas sawit di Desa Rabuhit. Padahal dilihat dari harga tepas yang bermotif memiliki harga lebih besar yaitu Rp 25.000 - 35.000 perlembar dari pada motif biasa dengan harga Rp 9.000 perlembarnya.

\section{Strategi Pengembangan Usaha Kerajinan Tepas Sawit}

\section{Penentuan Alternatif Strategi}

Penentuan alternatif strategi yang sesuai bagi pengembangan usaha kerajinan tepas dari pelepah sawit adalah dengan cara membuat matrik SWOT. Matrik SWOT ini dibangun berdasarkan faktor-faktor strategi baik internal yang terdiri dari kekuatan dan kelemahan maupun strategi eksternal yang terdiri dari peluang dan ancaman.

Berdasarkan Matrik SWOT maka dapat disusun empat strategi utama yaitu SO, WO, ST, dan WT. 


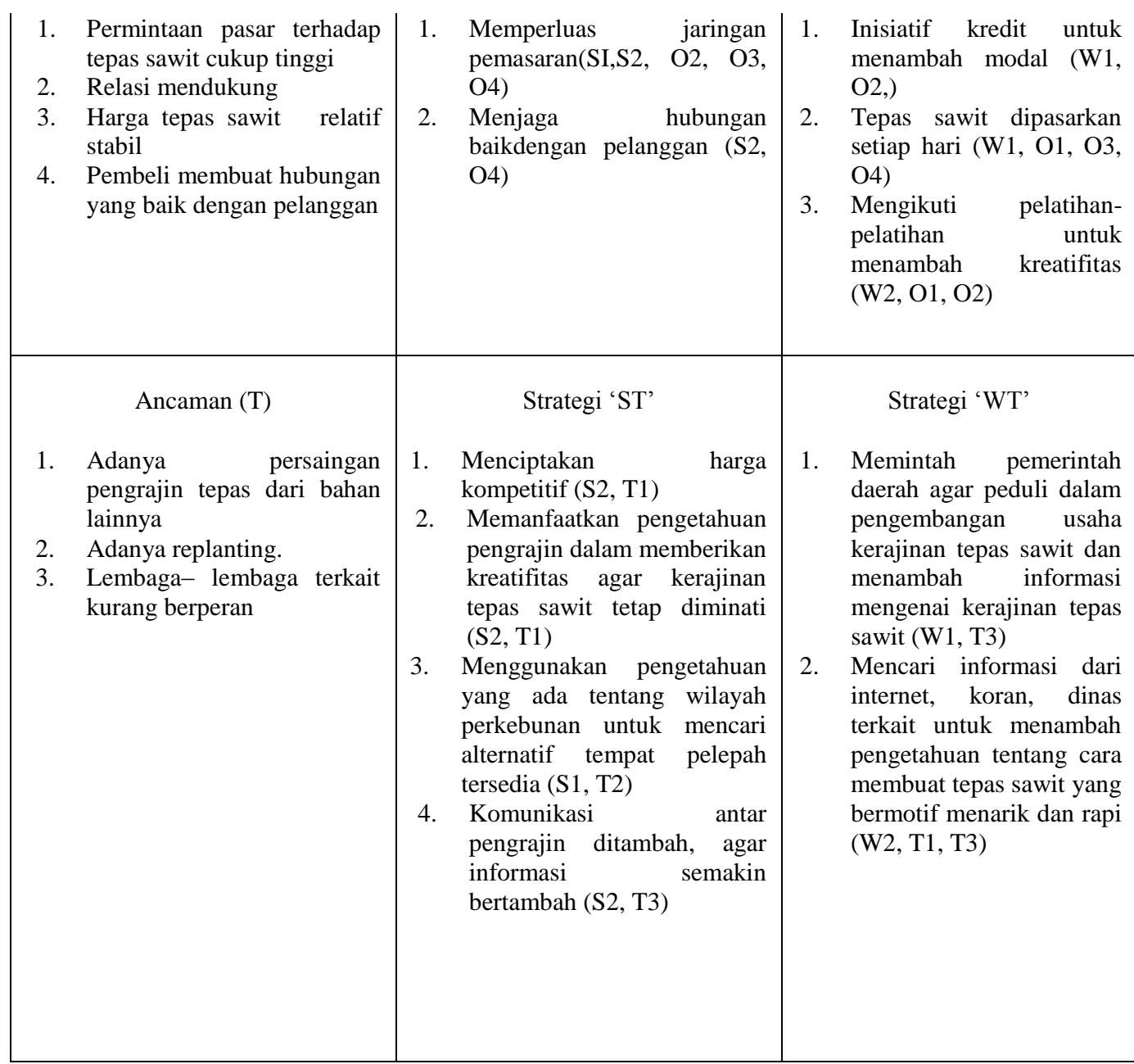

\section{Strategi 'SO'}

Strategi pengembangan usaha kerajinan tepas sawit dari pelepah sawit di Desa

Rabuhit dengan menggunakan seluruh kekuatan untuk memanfaatkan peluang yang ada, yaitu :

1. Memperluas jaringan pemasaran (S1, S2, $\mathrm{O} 2, \mathrm{O} 3, \mathrm{O} 4)$

Bertujuan untuk meningkatkan hasil produksi kerajinan tepas sawit untuk memenuhi permintaan pasar dengan didukung oleh harga yang relatif stabil sehingga dapat meningkatkan pendapatan pengrajin tepas sawit di Desa Rabuhit

2. Menjaga hubungan baik dengan pelanggan $(\mathrm{S} 2, \mathrm{O} 4)$

Bertujuan agar pelanggan tidak beralih ke pengrajin lain yang dapat menyebabkan kerugian bagi pengrajin yang bersangkutan.

\section{Strategi 'WO'}

Strategi pengembangan usaha kerajinan tepas sawit di Desa Rabuhit dengan meminimalkan kelemahan untuk memanfaatkan peluang yang ada, yaitu :
1. Inisiatif kredit untuk menambah modal (W1, $\mathrm{O} 2$,)

Skala usaha yang lebih luas umumnya bermodal besar namun demikian dapat memperkecil biaya usaha kerajinannya, sehingga dapat meningkatkan pendapatan keluarga.

2. Tepas sawit dipasarkan setiap hari (W1, O1, $\mathrm{O} 3, \mathrm{O} 4)$

Informasi pasar yang luas dengan didukung oleh hubungan yang baik dengan pembeli, dapat menyebabkan kerajinan tepas sawit yang dihasilkan setiap harinya dapat terjual semuanya.

3. Mengikuti pelatihan-pelatihan untuk menambah kreatifitas (W2, O1, O2)

Pengrajin dapat mengetahui bagaimana cara memberikan nilai tambah pada kerajinan tepas sawit sehingga pengrajin dapat meningkatkan pendapatan keluarganya.

\section{Strategi ' $\mathbf{S T}$}

Strategi pengembangan usaha kerajinan tepas sawit di Desa Rabuhit dengan menggunakan seluruh kekuatan untuk mengatasi ancaman yang ada, yaitu:

1. Menciptakan harga kompetitif (S2, T1) 
Bertujuan agar pasar kerajinan tepas sawit tetap ada, sehingga usaha kerajinan tepas sawit tetap eksis.

2.Memanfaatkan pengetahuan pengrajin dalam memberikan sentuhan kreatifitas agar kerajinan tepas sawit tetap menarik (S2, T1)

Bertujuan agar terpenuhinya kebutuhan konsumen khususnya bagi para pengusaha yang ingin bangunan usahanya lebih menarik sehingga pengusaha senang memakai tepas sawit yang diproduksi pengrajin.

3. Menggunakan pengetahuan yang ada tentang wilayah perkebunanyang menghasilkan limbah pelepah sawit agar tersedianya bahan baku tepas sawit $(\mathrm{S} 1, \mathrm{~T} 2)$

Bertujuan agar produksi yang dihasilkan setiap harinya optimal sehingga keuntungan yang diperoleh pengrajin maksimal.

4. Komunikasi antar pengrajin ditambah, agar informasi semakin bertambah (S2, T3)

Bertujuan agar terjalin kerjasama yang baik dan dapat memecahkan masalah secara bersama-sama, sehingga tujuan lebih mudah tercapai yaitu memperoleh laba yang maksimal.

\section{Strategi 'WT'}

Strategi pengembangan usaha kerajinan tepas sawit di Desa Rabuhit dengan meminimalkan kelemahan untuk mengatasi ancaman yang ada, yaitu :

1. Meminta pemerintah agar peduli dalam pengembangan kerajinan tepas sawit, dan menambah informasi mengenai kerajinan tepas sawit (W1, T3).

Bertujuan untuk memberikan pengetahuan kepada pengrajin yang akan membuat tepas sawit dengan inovasi dan motif yang baru, cara-cara pembuatannya serta memberikan modal yang lebih besar. Sehingga dapat meningkatkan produksi dan berkembangnya usaha kerajinan tepas sawit tersebut.

2. Mencari informasi dari internet, koran, dinas terkait untuk menambah pengetahuan tentang cara membuat tepas sawit yang bermotif dan rapi (W2, T1, T3)

Pengrajin perlu mengetahui informasi bagaimana membuat tepas sawit, terutama untuk motif dan kerapian tepas sawit tersebut. Diberbagai daerah di luar Desa Rabuhit sudah semakin banyak tepas sawit dengan bahan lain yang lebih berkualitas, sehingga informasi yang didapat sangat membantu dalam memproduksi kerajinan tepas sawit yang lebih bagus. Sehingga dapat menjadi sebuah usaha berwawasan agribisnis, yang pada akhirnya juga akan menambah pendapatan kelurga pengrajin tepas sawit di Desa Rabuhit.

\section{Penentuan Prioritas Strategi Pengembangan Usaha Kerajinan Tepas Sawit}

Tidak ada satu Organisasi pun yang memiliki sumber daya yang tidak terbatas. Oleh karena itu tidak ada satu organisasi pun yang dapat menjalankan semua strategi yang berpotensi menguntungkan. Keputusan keputusan strategis harus selalu dibuat untuk memilih kegiatan yang paling tepat dan mengalokasikan sumber daya organisasi. Kebanyakan organisasi hanya dapat menerapkan sedikit strategi tingkat perusahaan dalam satu waktu tertentu. Merupakan suatu kesalahan besar bagi manajer bila terlalu banyak menerapkan strategi pada saat yang sama. Karena akan menguras sumber daya perusahaan sehingga setiap strategi menjadi tidak optimal dan rentan.

Dari hasil analisis matriks SWOT telah diperoleh sebelas alternatif strategi yang bisa diterapkan untuk penegembangan usaha kerajinan tepas sawit di Desa Rabuhit. Untuk menentukan prioritas strategi yang paling tepat dan utama maka dilakukan analisis untuk pengambilan keputusan yang memberikan gambaran kelebihan - kelebihan relatif dari masing - masing strategi. Yang selanjutnya memberikan dasar objektif untuk dapat memilih salah satu atau beberapa strategi paling penting yang dapat menjadi pilihan utama. Langkah selanjutnya adalah mencari alternatif strategi yang dapat diterapkan sehingga terpilih lima strategi, yaitu :

1. Memperluas jaringan pemasaran dengan tujuan meningkatkan produksi tepas sawit untuk memenuhi permintaan pasar dengan didukung oleh harga yang relatif stabil (kompetitif).

2. Perluasan usaha kerajinan tepas sawit dengan cara meminta bantuan pemerintah agar peduli dalam pengembangan usaha kerajinan tepas sawit melalui penyediaan modal pengembangan usaha. Dan adanya pertukaran informasi antar pengrajin tepas sawit untuk menghadapi persaingan tepas sawit dengan bahan lain di luar daerah.

3. Memberikan nilai tambah/sentuhan kreatifitas yaitu membuat motif tepas sawit yang lebih menarik.

4. Menjaga hubungan baik dengan konsumen tepas sawit.

5. Menggunakan pengetahuan yang ada tentang wilayah perkebunan penghasil limbah pelepah sawit untuk menjaga ketersediaan bahan baku produksi tepas sawit. 


\section{KESIMPULAN DAN SARAN}

\section{Kesimpulan}

Kontribusi usaha kerajinan tepas sawit terhadap pendapatan rumah tangga di Desa Rabuhit sebesar Rp 44.228.250 yaitu 56\% dari total pendapatan rumah tangga.

Kendala-kendala yang dihadapi pengrajin tepas sawit di Desa Rabuhit adalah modal pengembangan usaha, manajemen usaha yang tidak dilakukan dengan baik dan tidak ada dukungan kelembagaan

Strategi pengembangan usaha kerajinan tepas sawit dapat dilihat dari potensi dan kendala-kendala yang dihadapi pengrajin yaitumemperluas jaringan pemasaran, perluasan usaha kerajinan tepas sawit, memberikan nilai tambah/sentuhan kreatifitas yaitu membuat motif tepas sawit yang lebih menarik, menjaga hubungan baik dengan konsumen tepas sawit dan menggunakan pengetahuan yang ada tentang wilayah perkebunan penghasil limbah pelepah sawit untuk menjaga ketersediaan bahan baku produksi tepas sawit.

\section{Saran}

Kepada Pengrajin agar meningkatkan produktifitas kerajinan tepas sawit dengan melihat permintaan pasar. Misalnya dalam memberi nilai tambah pada tepas sawit dengan menciptakan model atau corak tepas yang lebih menarik. Sehingga dapat meningkatkan pendapatan pengrajin.

\section{DAFTAR PUSTAKA}

1. Mubyarto, 1994.Pengantar Ekonomi Pertanian.LP3ES. Jakarta.

2. Baroh, I. 2007. Analisis Nilai Tambah dan Distribusi Keripik Nangka Studi Kasus pada Agroindustri Keripik
Nangka di Lumajang. LP UMM. Malang.

3. Saragih, B.2004. Membangun Pertanian dalam Perspektif Agrobisnis dalam Ruang.Raja Grafindo Persada. Jakarta

4. Adi, P. 2010. Kaya dengan Bertani Kelapa Sawit. Pustaka Baru Press. Yogyakarta

5. Anneahira. 2012. Situs kayu anyaman. (online)

http://www.anneahira.com/kayu anyaman.html. diakses pada tanggal 27 Desember 2014.

6. Fauzi, Y., Widyastuti, Y.E., Satyawibawa, I dan Paeru, R.H. 2006.Kelapa Sawit Seri Agribisnis. Jakarta: Penebar Swadaya.

7. Anonimus. 2012. Situs Pengertian Tepas.(Online)http://Artikata.com/966 38/tepas.html.diakses pada tanggal 28 Desembar 2014

8. Tohir, k.1991.Seuntai Pengetahuan Usaha Tani Indonesia. Rineka Cipta.Jakarta

9. Sugiyono, 2010.Metode Penelitian Kuantitatif Kualitatif dan $R \& D$. Jakarta:Alfabeta

10. Andriyanto, U.S dan Basith, A.1999.Metode dan Aplikasi Peramalan. Erlangga. Jakarta

11. Rangkuti, 2014. Analisis SWOT. Gramedia Pustaka Umum.Jakarta 